\title{
Paradoks funduszy zamkniętych - wpływ decyzji inwestorów na wycenę giełdową certyfikatów inwestycyjnych na przykładzie polskich funduszy zamkniętych
}

\author{
The closed-end fund puzzle - the behavior \\ of investors and the stock exchange valuation \\ of investment certificates
}

Artur Arkadiusz Trzebiński

Wydział Przyrodniczo-Technologiczny, Uniwersytet Przyrodniczy we Wrocławiu, arturtrzebinski@gmail.com

\section{Streszczenie:}

W artykule przedstawiono anomalie związane z istnieniem różnicy między giełdową wyceną tytułów uczestnictwa w funduszach inwestycyjnych zamkniętych a wyceną księgową (określane jako paradoks funduszy zamkniętych). Istnienie anomalii wyjaśnia się, uwzględniając dwie różne grupy czynników. Pierwszą z nich są czynniki fundamentalne, takie jak zobowiązania podatkowe czy koszty transakcyjne. Drugą grupę stanowią czynniki behawioralne, w szczególności nieracjonalność inwestorów. Głównym celem artykułu jest zbadanie wpływu czynników behawioralnych na występowanie i poziom paradoksu polskich funduszy zamkniętych. Badaniem objęto grupę 40 funduszy, które realizują odmienne strategie inwestycyjne i znajdują się na różnych etapach funkcjonowania. Na podstawie uzyskanych wyników można stwierdzić, że decyzje nieracjonalnych inwestorów powodują obniżanie ceny gieł- dowej certyfikatów w stosunku do wartości księgowej. Wykazano także, że wysokość dyskonta/premii zależy od etapu funkcjonowania funduszy inwestycyjnych.

Stowa kluczowe: fundusze inwestycyjne zamknięte, paradoks funduszy zamkniętych, sentyment inwestora.

\section{Abstract:}

This article presents anomalies associated with the existence of the difference between the stock market valuation of shares in closed-end investment funds and their book value (referred to as the closed-end fund puzzle). The existence of anomalies is explained on the basis of two different groups of factors. The first of these are the fundamental factors, such as tax liabilities and transaction costs. The second group consists of behavioral factors, in particular the irrationality of investors. The main purpose of this article 
is to examine the impact of behavioral factors on the occurrence and level of the closed-end fund paradox. The study group consisted of 40 funds that followed different investment strategies and were in various stages of operation. The results showed that investors made irrational decisions that lowered the stock price of certificates in relation to their book value. It was also shown that the amount of the discount/premium depends on the phase of the investment funds.

Keywords: closed-end mutual funds, closed-end funds puzzle, investor sentiment.

\section{Wprowadzenie}

Fundusze inwestycyjne zamknięte inwestują w różne klasy aktywów i emitują tytuły uczestnictwa, które w większości przypadków są przedmiotem obrotu giełdowego. Liczba wyemitowanych tytułów uczestnictwa w okresie działalności funduszu ulega zmianie tylko w dwóch przypadkach - wyemitowania nowej serii oraz wykupienia ich przez fundusz. Zarówno emisje nowych serii tytułów uczestnictwa, jak i umorzenia odbywają się w określonym czasie i terminie. Innym obowiązkiem funduszu jest informowanie posiadaczy tytułów uczestnictwa o wartości aktywów netto przypadających na jeden tytuł, co odbywa się codziennie, raz w miesiącu lub co kwartał. Oznacza to, że fundamentalna wartość aktywów netto przypadająca na tytuł uczestnictwa nie powinna znacząco odbiegać od wartości tytułów notowanych na rynku giełdowym i powinna być uzależniona od popytu na nie. W rzeczywistości ceny tytułów inwestycyjnych notowanych na rynku wtórnym znacznie odbiegają od wyceny księgowej (średnio dyskonto zawiera się w przedziale 5-10\%), co w literaturze określa się jako paradoks funduszy zamkniętych (closed-end fund puzzle).
Dotychczasowe, nieliczne badania poświęcone paradoksowi funduszy zamkniętych (Szyszka, Zaremba, 2009; Stępień, 2010; Pauka, Prędkiewicz, 2012, 2015) wskazują na występowanie tej anomalii również na polskim rynku. Przedstawione $\mathrm{w}$ artykule badanie jest rozwinięciem oraz uzupełnieniem wcześniejszych analiz, które przeprowadzili wymienieni autorzy.

Celem pracy jest zbadanie występującego na polskim rynku paradoksu funduszy zamkniętych w latach 2002-2015 i uzyskanie odpowiedzi na dwa pytania: jak zachowanie inwestorów wpływa na kształtowanie się cen certyfikatów inwestycyjnych oraz czy na poziom rozbieżności między ceną giełdową certyfikatów inwestycyjnych a wartością księgową ma wpływ etap działalności funduszy.

\section{Istota paradoksu funduszy zamkniętych}

Paradoks funduszy zamkniętych sprowadza się do czterech zasadniczych kwestii. Po pierwsze, tytuły uczestnictwa nowo wprowadzanych na rynek giełdowy funduszy notowane są powyżej wartości księgowej oraz po upływie kilku miesięcy po debiucie ich wartość spada poniżej tej wartości. Po drugie, tytuły uczestnictwa większości funduszy wyceniane są z dużym dyskontem w stosunku do ich wartości aktywów netto. Po trzecie, poziom dyskonta i premii charakteryzuje się wysoką zmiennością w krótkim i długim okresie. Po czwarte, w końcowym etapie działalności funduszy (połączenia $z$ innym funduszem czy zamiany $\mathrm{w}$ fundusz otwarty) wysokość dyskonta w cenie rynkowej tytułów uczestnictwa zbliża się do wartości księgowej.

Występowanie różnicy między ceną giełdową a wartością księgową próbuje się wyjaśnić wieloma teoriami, które można podzielić na dwie grupy. Pierwszą stanowią racjonalne (fun- 
damentalne) teorie, które bazują na kosztach transakcyjnych, zobowiązaniach podatkowych, błędnej wycenie wartości aktywów oraz płynności aktywów. Do drugiej grupy zalicza się teorie oparte na czynnikach behawioralnych, w szczególności na koncepcji nastroju inwestorów indywidualnych (noise traders). W literaturze przedmiotu zwraca się uwagę na uzyskiwanie niejednoznacznych wyników weryfikacji zarówno teorii racjonalnych, jak i behawioralnych, przy czym większość badaczy zwraca się ku teoriom behawioralnym. Przegląd i omówienie literatury zawarte są w artykułach (Dimson, $\mathrm{Mi}^{-}$ nio-Kozerski, 1999; Dimson, Minio-Paluello, 2002; Charrón, 2009; Cherkes, 2012; Fletcher, 2013; Chu, Ma 2015; Lenkey, 2015).

Fundamentalne teorie tylko częściowo wyjaśniają istnienie dyskonta, nie tłumaczą wysokiej zmienności dyskonta i premii ani występowania premii przy pierwszych notowaniach tytułów uczestnictwa. W odniesieniu do motywu kosztowego wystarczy wskazać, że koszty funkcjonowania funduszy, w tym koszty zarządzania, są utrzymywane na zbliżonym poziomie przez cały okres działalności funduszu, w przeciwieństwie do poziomu dyskonta i premii, które zmieniają się nawet codziennie. Dodatkowo poniesione przez fundusz koszty uwzględnione są w wycenie księgowej i trudno na jej podstawie ocenić, co miało znaczący wpływ na tę wartość - poniesione koszty czy decyzje inwestycyjne zarządzających. Z kolei dyskontowanie w cenie tytułów uczestnictwa zobowiązań podatkowych też należy uznać za niewystarczające, ze względu na występowanie dyskonta i premii niezależnie od wysokości podatku od zysków kapitałowych. Natomiast argument o błędnej wycenie wartości aktywów i ich płynności nie wyjaśnia istnienia paradoksu. Aktywa z ograniczonymi możliwościami zbycia wyceniane są za pomocą wartości godziwej przez odpowied- nie podmioty, co pozwala określić ich wartość rynkową. Ponadto paradoks występuje zarówno w przypadku funduszy lokujących środki w aktywa trudno zbywalne, jak i o wysokiej płynności (Cieślak, 2003).

Podstawą teorii behawioralnej jest zaproponowany przez C.M.C. Lee, A. Shleifera i R.H. Thalera $(1990,1991)$ podział inwestorów na racjonalnych i nieracjonalnych (noise traders), którzy kierują się w swoich decyzjach inwestycyjnych sentymentem do danego aktywa oraz własnymi przekonaniami co do przyszłych cen aktywów. Teoria noise traders nawiązuje do koncepcji J.B. De Longa, A. Shleifera, L.H. Summersa i R.J. Waldmanna (1990) oraz A. Shleifera i L.H. Summersa (1990) o występowaniu dodatkowego ryzyka systematycznego i ograniczeń arbitrażu.

Początkowe notowania tytułów uczestnictwa powyżej wartości księgowej wynikają z przewagi racjonalnych inwestorów oraz ich działań, których celem jest jak najdłuższe utrzymanie premii (Szyszka, 2007). R. Thompson (1978) oraz C.M.C. Lee i in. (1990) zwracają uwagę na zależność występowania rozbieżności między ceną giełdową a wartością aktywów netto funduszy $\mathrm{z}$ nieprzewidywalnością zmian nastrojów nieracjonalnych inwestorów i ich gwałtownymi reakcjami na negatywne informacje. C.M.C. Lee i in. (1990) wykazali, że oddziaływanie to utrzymuje się zarówno w krótkim, jak i dlugim okresie. Badania K. Weiss (1989) oraz J.W. Peavy'ego (1990) wskazują, że po upływie od trzech do sześciu miesięcy po debiucie wartość tytułów uczestnictwa spada poniżej wyceny księgowej. Jako główny czynnik różnicy badacze wskazali zmianę struktury inwestorów - wzrost udziału drobnych (nieracjonalnych) inwestorów, oraz ograniczenia arbitrażu. Arbitrażyści mogą nie podejmować działań ze względu na występowanie ryzyka noise traders, 
za które wymagają wyższych stóp zwrotu oraz braku możliwości odwzorowania portfeli funduszy zamkniętych. W miarę wycofywania się racjonalnych inwestorów $z$ obrotu tytułami uczestnictwa coraz większy wpływ na wysokość dyskonta/premii mają drobni inwestorzy. J.A. Brickley i J.S. Schallheim (1985) zwracają uwagę na kształtowanie się wysokości dyskonta w końcowym etapie działalności funduszy, które ulega obniżeniu. Im bliżej do terminu likwidacji funduszu lub przekształcenia $\mathrm{w}$ fundusz otwarty, tym mniejszy jest wpływ nieracjonalnych inwestorów i zwiększony udział racjonalnych inwestorów, którzy liczą na szybkie zbliżanie się ceny tytułów uczestnictwa do wartości księgowej.

W literaturze podkreśla się również występowanie korelacji między poziomem dyskonta/premii różnych rodzajów funduszy oraz $\mathrm{z}$ innymi klasami instrumentów finansowych najczęściej kupowanych przez drobnych inwestorów. N. Chopra, C.M.C. Lee, A. Shleifer i R.H. Thaler (1993) wykazali wplyw sentymentu inwestorów na ceny akcji małych spó1ek, natomiast J.N. Bodurtha, K. Dong-Soon i Lee (1995) - na ceny papierów wartościowych emitowanych przez rządy państw. Kolejnego argumentu o słuszności teorii sentymentu inwestorów dostarczają wyniki badań S. Andersona, T.R. Bearda, H. Kima i L.V. Sterna (2013), którzy wykazali wysoką korelację między poziomem dyskonta funduszy zamkniętych i ,indeksem strachu" (volatility index).

Występowanie paradoksu funduszy zamkniętych w polskich warunkach weryfikowało kilku badaczy. Pierwszą analizę tego zjawiska przeprowadzili A. Szyszka i A. Zaremba (2009), a kolejne dwie - M. Pauka i P. Prędkiewicz (2012, 2015). We wcześniejszej publikacji M. Stępień (2010) ograniczyła się do opisania poziomu dyskonta/premii $\mathrm{z}$ jednej sesji. A. Szyszka i A. Zaremba (2009) wykazali istnienie dyskonta $\mathrm{w}$ wysokości 4,1\% na próbie 15 funduszy o średniej i wysokiej płynności w okresie od maja 2002 r. do listopada 2008 r., bez wskazywania źródła rozbieżności między ceną certyfikatów a WANCI. Z kolei w badaniach M. Pauki i P. Prędkiewicza (2012, 2015) zostały zbadane czynniki wpływające na powstawanie paradoksu, przy czym właściwe badanie było ograniczone do jednego funduszu.

\section{Metoda}

\subsection{Próba badawcza}

Zgodnie z obowiązującymi przepisami prawa w Polsce emitentami tytułów uczestnictwa $\mathrm{w}$ funduszu inwestycyjnym mogą być wyłącznie fundusze inwestycyjne zamknięte. Wycena wartości aktywów netto przypadająca na jeden certyfikat inwestycyjny (WANCI) musi odbywać się co najmniej raz na kwartał, z czego korzysta większość działających funduszy. Dodatkowo większość funduszy umożliwia inwestorom odsprzedanie im certyfikatów tylko kilka razy w roku. Pomimo tego ograniczenia rynek obrotu wtórnego certyfikatami inwestycyjnymi jest rynkiem o niskiej kapitalizacji i małej aktywności uczestników. W latach 2002-2015 na Giełdzie Papierów Wartościowych (GPW) w Warszawie notowane były łącznie 102 certyfikaty inwestycyjne, $\mathrm{z}$ czego w ponad połowie nie przeprowadzono ani jednej transakcji.

Przedmiotem analizy były ceny certyfikatów inwestycyjnych funduszy zamkniętych notowanych na GPW w Warszawie w okresie od 14 maja 2002 r. do 30 czerwca 2015 r. Z próby badawczej wyeliminowano certyfikaty całkowicie niepłynne oraz notowane krócej niż na 120 sesjach. Pierwszy warunek wykluczył 61 funduszy, a drugi - jeden fundusz. Ostatecznie próba 
Tabela 1. Liczba sesji przypadająca na etapy funkcjonowania funduszy

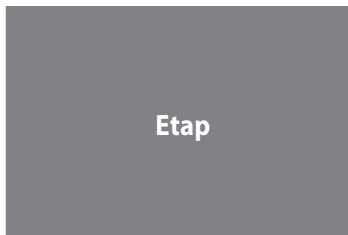

Budowanie portfela inwestycyjnego

Zarządzanie lokatami

Przygotowanie do likwidacji

Źródto: opracowanie własne.
Fundusze utworzone na czas nieokreślony zlikwidowane przed

Fundusze utworzone na czas nieokreślony terminem oraz fundusze

utworzone na czas określony

250

250

pozostały okres

nie dotyczy pozostały okres

125
500
Fundusze

nieruchomości

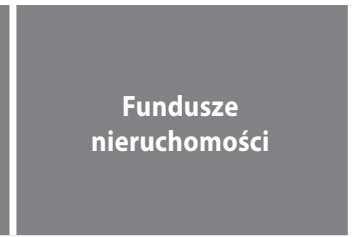

500

pozostały okres

125

badawcza objęła 40 funduszy inwestycyjnych realizujących odmienne strategie inwestycyjne i lokujące aktywa w różne instrumenty finansowe. Wykorzystane w badaniu dane empiryczne pochodzą z autorskiej bazy danych o funduszach inwestycyjnych oraz raportów bieżących publikowanych przez fundusze inwestycyjne $\mathrm{w}$ serwisie informacyjnym GPW w Warszawie (gpwinfosfera.pl).

Grupa badawcza obejmowała 10 funduszy akcyjnych, trzy surowcowe, dwa absolutnej stopy zwrotu, pięć dłużnych, osiem nieruchomości oraz 12 mieszanych z ochroną kapitału. Ze względu na niską liczbę w analizie połączono fundusze surowcowe i absolutnej stopy zwrotu (określane dalej jako pozostałe). Jeżeli chodzi o etapy funkcjonowania funduszy, dziesięć funduszy zakończyło działalność w planowanym terminie, trzy zlikwidowano przed datą zapadalności, jeden wycofał certyfikaty z rynku wtórnego $\mathrm{w}$ trakcie działalności, a pozostałe były na etapie zarządzania lokatami.

\subsection{Proces badawczy}

Pierwszym etapem badania było wyznaczenie dla każdego funduszu i każdej sesji wartości dyskonta/premii, które obliczono zgodnie ze wzorem:

dyskonto $/$ premia $=\ln$ (cena certyfikatu

inwestycyjnego $z$ sesji $n$ / ostatnia, najbliższa

sesji $n$ wartość aktywów netto przypadająca na certyfikat inwestycyjny).

Następnym etapem było uśrednienie dziennych wyników dyskonta/premii dla całego okresu badawczego, okresów rocznych (kalendarzowych) oraz okresów obejmujących etapy funkcjonowania funduszy - budowanie portfela inwestycyjnego, zarządzanie lokatami i przygotowanie do likwidacji. Opierając się na planowanym okresie działalności i rodzaju funduszy, przyjęto różne długości trwania poszczególnych etapów, przyjmując przeciętnie 250 sesji w roku (dane zawarto w tabeli 1). Nałożone kryteria zmniejszyły próbę badawczą o jeden fundusz, ze względu na zbyt krótki okres działalności (139 miesięcy).

W kolejnym etapie obliczone poziomy dyskonta/premii zostały poddane analizie historycznej, aby sprawdzić, czy na polskim ryn$\mathrm{ku}$ występują tendencje zaobserwowane na innych rynkach. Szczególną uwagę zwrócono na pierwszych 120 notowań. Dodatkowo przeprowadzono analizę poziomu dyskonta/premii 
na poszczególnych etapach funkcjonowania funduszy.

W pierwszym kroku ostatniego etapu sprawdzono korelację rangową ${ }^{1}$ pomiędzy różnymi rodzajami funduszy. Następnie zbadano, czy istnieje związek między cenami certyfikatów inwestycyjnych a indeksami giełdowymi. Wybrano dwa indeksy giełdowe - WIG i sWIG80 oraz wskaźnik InvestorMS. Indeksu WIG użyto w celu sprawdzenia, czy ogólna sytuacja na giełdzie ma wpływ na ceny certyfikatów, a indeksu sWIG80 - ze względu na reprezentowanie małych spółek, w które najchętniej inwestują drobni inwestorzy, i jego wrażliwość na działanie inwestorów nieracjonalnych. Z kolei wskaźnik InvestorMS ocenia zachowanie małych i średnich spółek oraz jest benchmarkiem dla funduszu inwestycyjnego $\mathrm{z}$ segmentu małych i średnich spółek. Dzięki częstej selekcji spółek wykazuje on niską wrażliwość na zachowania inwestorów nieracjonalnych.

\section{Wyniki badań}

\subsection{Zmiany wartości i zmienność dyskonta/premii}

Przeciętny poziom dyskonta/ premii w badanym okresie wynosi - $11,0 \%$ dla wszystkich funduszy (przy odchyleniu standardowym 16,9\% oraz średniej stopie zwrotu -0,1\%). W każdym roku badanego okresu występowało dyskonto, którego wartość waha się od $-18,2 \%$ do $-1,0 \%$. Średnioroczne wartości dyskonta/premii dla poszczególnych rodzajów funduszy zawierają się w przedziale od $-39,5 \%$ do $10,1 \%$. Najniższa

\footnotetext{
1 Zdecydowano o wykorzystaniu korelacji rang Spearmana ze względu na nieprostoliniowe zależności oraz występowanie obserwacji odstających, których wyeliminowanie wpływa na uzyskane wyniki.
}

wartość dyskonta występuje w przypadku funduszy surowcowych i absolutnej stopy zwrotu $-3,5 \%$ (odchylenie standardowe $4,1 \%$ i średnia stopa zwrotu 0,0\%), a najwyższa - przy funduszach nieruchomości -27,5\% (odchylenie standardowe $21,2 \%$ i średnia stopa zwrotu -0,3\%). Dla poszczególnych funduszy (tabela 2) rozbieżność między ceną giełdową a wartością księgową waha się od dyskonta w wysokości $-88,0 \%$ do premii $59,4 \%$.

Porównując średnioroczne stopy zwrotu badanych funduszy z przeciętnymi wartościami dyskonta/premii, które przedstawiono na rysunku 1, można zauważyć powiązanie ze sobą tych wielkości. Spadek stóp zwrotu wpływa na zwiększenia dyskonta, a wzrost stóp zwrotu na zmniejszanie dyskonta. Średnioroczne stopy zwrotu badanych funduszy z przeciętnymi wartościami dyskonta/premii są powiązane w stopniu średnim (korelacja rang wynosi 0,4 i jest statystycznie istotna przy $p=0,05)$. Dla poszczególnych rodzajów funduszy korelacja rangowa ma słabą siłę i wynosi dla akcyjnych $-0,03$ (brak istotności statystycznej), dłużnych $0,2(p=0,05)$, mieszanych $z$ ochroną kapitału $0,1(p=0,05)$, nieruchomości $0,2(p=0,05)$ oraz pozostałych 0,04 (brak istotności statystycznej).

W latach 2002-2007 dyskonto stopniowo ulegało obniżeniu ( $\mathrm{z}-5,0 \%$ do $-1,0 \%$, przy wzroście stóp zwrotu z $0,2 \%$ do $1,3 \%$ ), a nawet w przypadku funduszy nieruchomości wystąpiło zwiększenie premii z $0,3 \%$ do $10,1 \%$ (zmiana stóp zwrotu z $0,8 \%$ do 2,3\%). W kolejnych latach, 20082015, fundusze osiągały coraz niższe średnie stopy zwrotu (spadek z $0,4 \%$ do $-1,1 \%$ ), a poziom dyskonta/premii uległ znacznej zmianie dwa razy. Po raz pierwszy w 2009 r. nastąpił ponad trzykrotny wzrost wysokości dyskonta wszystkich funduszy, na co największy wpływ miała zmiana poziomu dyskonta funduszy nieruchomości (wzrost z 4,5\% do 38,1\%). Druga zmiana 
Tabela 2. Średnioroczna wysokość dyskonta/premii (d/p, \%) i liczba nowych certyfikatów inwestycyjnych w latach 2002-2015

\begin{tabular}{|c|c|c|c|c|c|c|c|}
\hline Rok & Wszy & fundusze & Akcyjne & Pozostałe & Dłużne & Nieruchomości & $\begin{array}{l}\text { Mieszane } \\
\text { z ochroną }\end{array}$ \\
\hline$x$ & $d / p$ & $\begin{array}{l}\text { odchylenie } \\
\text { standardowe }\end{array}$ & $d / p$ & $d / p$ & $d / p$ & $d / p$ & $d / p$ \\
\hline 2002 & $-5,0$ & 3,9 & $-5,4$ & brak funduszy & $-3,7$ & brak funduszy & brak funduszy \\
\hline 2003 & $-4,1$ & 3,0 & $-6,3$ & brak funduszy & $-2,5$ & brak funduszy & $-3,6$ \\
\hline 2004 & $-4,1$ & 4,4 & $-4,5$ & brak funduszy & $-4,6$ & 0,3 & $-4,3$ \\
\hline 2005 & $-4,2$ & 4,1 & $-2,1$ & brak funduszy & $-4,0$ & 0,0 & $-6,0$ \\
\hline 2006 & $-2,5$ & 5,1 & $-0,8$ & $-2,6$ & $-2,8$ & 3,0 & $-4,4$ \\
\hline 2007 & $-1,0$ & 9,2 & 1,1 & $-3,1$ & $-3,8$ & 10,1 & $-4,3$ \\
\hline 2008 & $-4,2$ & 14,7 & $-3,6$ & $-3,9$ & $-4,0$ & $-4,5$ & $-4,4$ \\
\hline 2009 & $-12,8$ & 23,0 & $-10,4$ & $-1,7$ & $-3,6$ & $-38,1$ & $-1,1$ \\
\hline 2010 & $-12,1$ & 18,1 & $-13,1$ & $-2,5$ & $-4,1$ & $-29,8$ & $-1,9$ \\
\hline 2011 & $-13,1$ & 17,5 & $-12,5$ & $-4,4$ & $-4,6$ & $-28,6$ & $-3,3$ \\
\hline 2012 & $-18,2$ & 17,2 & $-15,7$ & $-4,3$ & $-3,6$ & $-34,4$ & $-10,8$ \\
\hline 2013 & $-16,5$ & 17,6 & $-13,9$ & $-4,6$ & $-3,0$ & $-34,1$ & $-8,1$ \\
\hline 2014 & $-13,2$ & 17,2 & $-7,0$ & $-2,8$ & $-2,5$ & $-39,5$ & $-4,2$ \\
\hline 2015 & $-10,7$ & 14,5 & $-6,8$ & $-3,3$ & $-2,1$ & $-36,9$ & $-3,7$ \\
\hline średnia & $-11,0$ & 16,9 & $-9,8$ & $-3,5$ & $-3,7$ & $-27,5$ & $-4,5$ \\
\hline $\min$. & $-88,0$ & $x$ & $-88,0$ & $-43,6$ & $-17,8$ & $-78,1$ & $-31,1$ \\
\hline maks. & 59,4 & $x$ & 59,4 & 12,4 & 3,6 & 54,4 & 39,5 \\
\hline
\end{tabular}

Źródło: opracowanie własne.

miała miejsce w 2012 r. - rozbieżność między ceną certyfikatów inwestycyjnych a WANCI wszystkich funduszy osiągnęła maksymalną wartość (-18,2\%). W kolejnych latach wysokość dyskonta stopniowo zmniejszała się dla wszystkich funduszy oraz poszczególnych rodzajów.

W badanym okresie największy wolumen obrotu zaobserwowano dla funduszy nieruchomości (sprzedano prawie $2 \mathrm{mln}$ certyfikatów inwestycyjnych). Niższe wolumeny uzyskały fundusze dłużne i mieszane $\mathrm{z}$ ochroną kapitału (odpowiednio 1,34 i 1,28 mln) oraz akcyjne i pozostałe $(0,8$ i $0,6 \mathrm{mln})$. W ujęciu ilościowym najwięcej transakcji przeprowadzono na certyfikatach funduszy akcyjnych (ponad 58 tys.) oraz funduszach nieruchomości (prawie 44 tys.). Pozostałe fundusze nie cieszyły się tak dużym zainteresowaniem ze strony inwestorów. $\mathrm{Na}$ certyfikatach funduszy surowcowych i absolutnej stopy zwrotu przeprowadzono ponad 21 tys. transakcji, a na funduszach dłużnych oraz mieszanych $\mathrm{z}$ ochroną kapitału - 10 i 5 tys. Na rysunku 2 przedstawiono liczbę transakcji oraz wolumen obrotu dla wszystkich funduszy. 


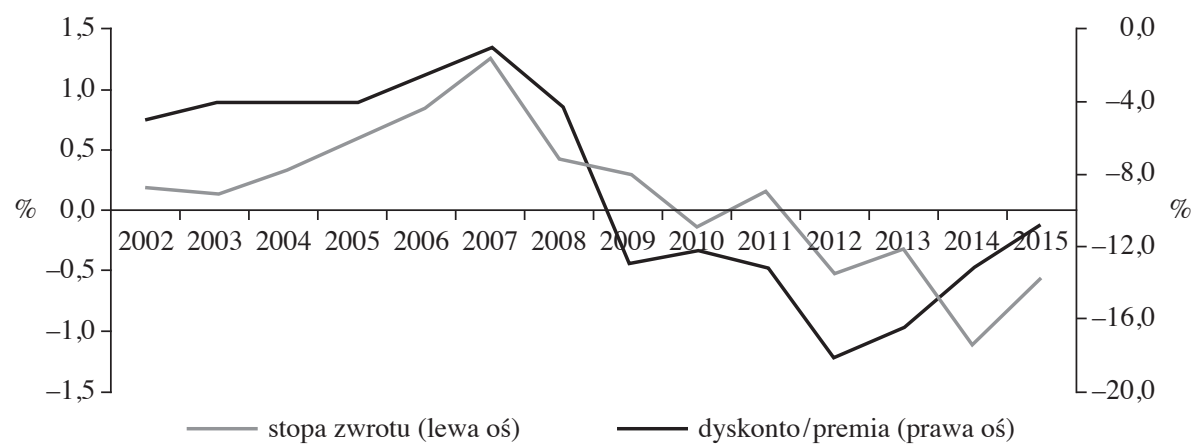

Rysunek 1. Poziom dyskonta / premii i stopy zwrotu funduszy inwestycyjnych w latach 2002-2015

Źródło: opracowanie własne.

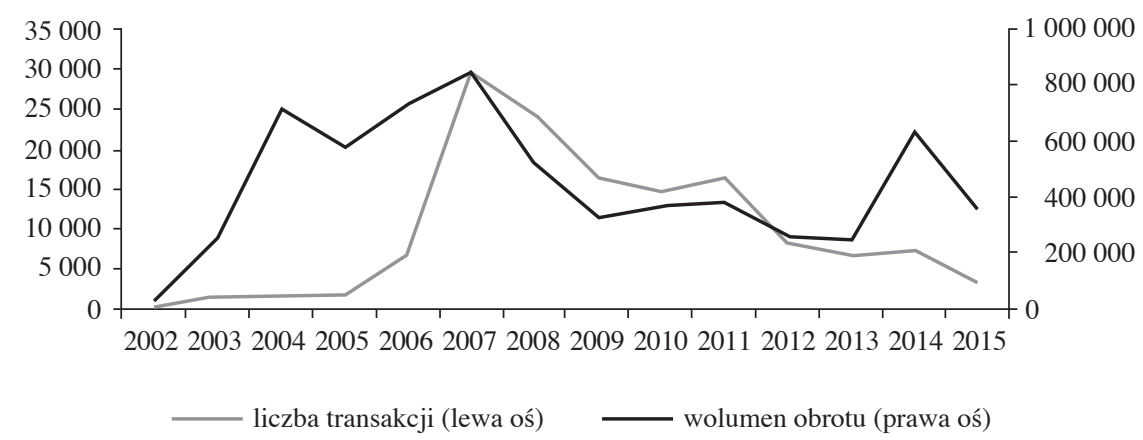

\section{Rysunek 2. Liczba transakcji i wolumen obrotu w latach 2002-2015}

Źródło: opracowanie własne.

Zestawienie ze sobą rocznych danych wskazuje na zmianę struktury inwestorów. W 2003 r. dominującymi uczestnikami byli inwestorzy instytucjonalni, o czym świadczy średnia wysokość wolumenu, niska liczba transakcji i bardzo wysoka wartość obrotu (tabela 3). W kolejnych latach widać znaczący wzrost udziału drobnych inwestorów, zwłaszcza w latach 2007 i 2008 oraz 2012-2015. Pierwszy podokres charakteryzuje się wysoką wartością obrotu i liczbą transakcji. Z kolei w drugim podokresie wszyst- kie zmienne mają przeciętne wartości. Należy dodać, że w tych podokresach dopuszczano do obrotu certyfikaty inwestycyjne głównie funduszy inwestycyjnych kierowanych do inwestorów indywidualnych.

Przyglądając się strukturze inwestorów w całym okresie badawczym, można zauważyć wysokie rozdrobnienie transakcji. Prawie 43\% przeprowadzonych transakcji nie przekroczyło wartości $10000 \mathrm{zł}$ i były to pojedyncze zlecenia sprzedaży od 1 do 100 certyfikatów. W prze- 
dziale od 10000 do 50000 zł wartości obrotu znalazło się 35\% ogólnej liczby transakcji.

\subsection{Poziom dyskonta/premii nowych certyfikatów inwestycyjnych}

Połowa badanych certyfikatów była notowana przez pierwszych 31 sesji powyżej wartości WANCI (w tym osiem mieszanych $z$ ochroną kapitału, sześć akcyjnych i cztery nieruchomości). Najdłuższe okresy notowania certyfikatów $\mathrm{z}$ premią występują w przypadku funduszy akcyjnych (70 sesji). Dla funduszy mieszanych z ochroną kapitału okres premii utrzymuje się średnio przez 31 sesji, funduszy nieruchomości - przez 16 i pozostałych - przez sześć. Dla funduszy dłużnych dyskonto utrzymywało się od pierwszej sesji. Natomiast certyfikaty wszyst- kich funduszy notowane były z premią tylko do ósmej sesji.

Przez pierwszych 30 sesji liczba transakcji i wolumenu obrotu miały najniższe wartości. Wraz z wydłużaniem okresu notowań wartości te ulegają zwiększaniu dla wszystkich rodzajów funduszy, przy stopniowym zwiększaniu udziału transakcji na niższe liczby certyfikatów inwestycyjnych (tabela 3).

\subsection{Zależność wysokości dyskonta/ premii od etapu funkcjonowania funduszu inwestycyjnego}

Jak wynika $\mathrm{z}$ danych zawartych w tabeli 4, $\mathrm{w}$ okresie budowania portfela inwestycyjnego wszystkie fundusze notowane były z dyskontem w wysokości 6,0\% przy wysokim zróżnicowa-

Tabela 3. Wysokość dyskonta / premii, liczba transakcji i wolumen obrotu w pierwszych 30-120 sesjach

\section{Liczba sesji}
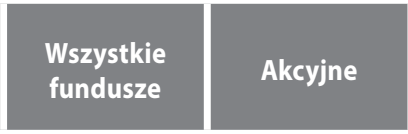
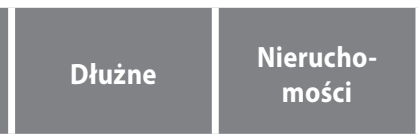

dyskonto / premia (\%)

\begin{tabular}{|lllllll|}
\hline 30 & $-0,4$ & 3,7 & $-2,9$ & $-2,7$ & $-3,8$ & 0,5 \\
\hline 60 & $-1,6$ & 4,4 & $-2,9$ & $-3,6$ & $-6,1$ & $-1,4$ \\
\hline 90 & $-2,1$ & 2,8 & $-2,9$ & $-3,7$ & $-7,2$ & $-2,3$ \\
\hline 120 & $-2,6$ & $-2,8$ & $-3,6$ & $-3,6$ & $-8,0$ & $-2,7$ \\
& & & & \\
\end{tabular}

\begin{tabular}{|c|c|c|c|c|c|c|}
\hline 30 & 83539 & 22578 & 5344 & 38662 & 9453 & 7501 \\
\hline 60 & 168712 & 36349 & 25760 & 65207 & 26964 & 14432 \\
\hline 90 & 256822 & 57109 & 36579 & 95833 & 42603 & 24698 \\
\hline \multirow[t]{2}{*}{120} & 390780 & 97257 & 53984 & 140341 & 64482 & 34716 \\
\hline & & & liczba tra & & & \\
\hline 30 & 5109 & 2998 & 1562 & 252 & 179 & 118 \\
\hline 60 & 10188 & 5005 & 3974 & 556 & 364 & 289 \\
\hline 90 & 15059 & 7223 & 5914 & 820 & 629 & 473 \\
\hline 120 & 19868 & 10006 & 7134 & 1129 & 953 & 646 \\
\hline
\end{tabular}

Źródło: opracowanie własne. 
Tabela 4. Wysokość dyskonta / premii (d/p), stopa zwrotu, wolumen obrotu i liczba transakcji w kolejnych etapach funkcjonowania funduszy inwestycyjnych

\begin{tabular}{|c|c|c|c|c|c|c|c|}
\hline \multirow[t]{2}{*}{ Etap } & $d / p$ & Odchylenie & Min & $\operatorname{Max}$ & $\begin{array}{l}\text { Stopa } \\
\text { zwrotu }\end{array}$ & $\begin{array}{l}\text { Wolumen } \\
\text { obrotu }\end{array}$ & $\begin{array}{c}\text { Liczba } \\
\text { transakcji }\end{array}$ \\
\hline & \multicolumn{7}{|c|}{$(\%)$} \\
\hline \multicolumn{8}{|c|}{ budowanie portfela } \\
\hline Wszystkie fundusze & $-6,0$ & 13,4 & $-64,4$ & 59,4 & 0,4 & 4778328 & 49051 \\
\hline $\begin{array}{l}\text { Fundusze utworzone na czas } \\
\text { nieokreślony }\end{array}$ & $-8,1$ & 15,7 & $-64,4$ & 59,4 & 0,2 & 4386099 & 43390 \\
\hline $\begin{array}{l}\text { Fundusze zlikwidowane przed } \\
\text { planowanym terminem }\end{array}$ & $-5,1$ & 5,3 & $-27,8$ & 9,5 & 1,4 & 36030 & 218 \\
\hline $\begin{array}{l}\text { Fundusze utworzone na czas } \\
\text { określony }\end{array}$ & $-1,2$ & 6,9 & $-19,8$ & 39,5 & 0,5 & 356199 & 5443 \\
\hline \multicolumn{8}{|c|}{ zarządzanie lokatami } \\
\hline Wszystkie fundusze & $-12,2$ & 17,2 & $-88,0$ & 54,4 & 4,9 & 4433062 & 96274 \\
\hline $\begin{array}{l}\text { Fundusze utworzone na czas } \\
\text { nieokreślony }\end{array}$ & $-12,0$ & 15,9 & $-78,1$ & 19,0 & 4,3 & 3218472 & 74268 \\
\hline $\begin{array}{l}\text { Fundusze zlikwidowane przed } \\
\text { planowanym terminem }\end{array}$ & $-5,5$ & 8,7 & $-30,2$ & 11,4 & 3,6 & 391058 & 583 \\
\hline $\begin{array}{l}\text { Fundusze utworzone na czas } \\
\text { określony }\end{array}$ & $-15,1$ & 23,1 & $-88,0$ & 54,4 & 7,2 & 823532 & 21423 \\
\hline \multicolumn{8}{|c|}{ przygotowywanie do likwidacji } \\
\hline Wszystkie fundusze & $-11,4$ & 20,9 & $-64,4$ & 26,4 & 0,8 & 5049303 & 19292 \\
\hline $\begin{array}{l}\text { Fundusze zlikwidowane przed } \\
\text { planowanym terminem }\end{array}$ & $-7,3$ & 5,1 & $-15,5$ & $-0,5$ & $-0,2$ & 118841 & 220 \\
\hline $\begin{array}{l}\text { Fundusze utworzone na czas } \\
\text { określony }\end{array}$ & $-13,0$ & 24,3 & $-64,4$ & 26,4 & 1,3 & 4930462 & 19072 \\
\hline
\end{tabular}

Źródło: opracowanie własne.

niu (odchylenie standardowe 13,4\%, wartości skrajne od dyskonta $-64,5 \%$ do premii $59,4 \%$ ). Najwyższy poziom dyskonta wykazały certyfikaty funduszy utworzonych na czas nieokreślony $(-8,1 \%)$, a najniższy - funduszy utworzonych na czas określony $(-1,2 \%)$.

W kolejnym etapie, zarządzania lokatami, przeciętna wysokość dyskonta dla wszystkich funduszy uległa podwojeniu przy zwiększeniu zróżnicowania (odchylenie standardowe 17,2\% - zmiana o 3,8 p.p., wartości skrajne -88,0\% i $54,4 \%)$. Wzrost poziomu dyskonta przełożył się na zmniejszenie liczby transakcji przy podwojeniu wolumenu obrotu. Znaczącą zmianę widać w wypadku funduszy utworzonych na czas określony, dla których poziom dyskonta był niższy aż o 14,0 p.p. przy czterokrotnym zwiększeniu wolumenu obrotu. Dla funduszy bez określonego terminu zakończenia wysokość dyskonta zwiększyła się o 4 p.p. przy zbliżonym poziomie odchylenia standardowego, spadku wartości skrajnych oraz znacznym spadku liczby transakcji i podwojeniu wolumenu obrotu. Natomiast dyskonto dla funduszy zlikwidowa- 
Tabela 5. Macierz korelacji rangowej poziomu dyskonta/premii funduszy inwestycyjnych

\begin{tabular}{lccccc} 
& Akcyjne & Dłużne & Mieszane & Nieruchomości & Pozostałe \\
Akcyjne & 1 & & & & \\
Dłużne & 0,07 & 1 & & \\
Mieszane & $0,1^{*}$ & $-0,03$ & 1 & 1 \\
Nieruchomości & $0,5^{*}$ & $-0,3^{*}$ & 0,01 & $-0,1^{*}$ & 1 \\
\hline Pozostałe & $0,1^{*}$ & $0,2^{*}$ & $0,3^{*}$ &
\end{tabular}

$* p=0,05$.

Źródto: opracowanie własne.

Tabela 6. Wartości wspótczynników korelacji rangowej poziomu dyskonta/premii z indeksami giełdowymi

\begin{tabular}{|lccc|}
\hline \multicolumn{1}{c}{ Rodzaj funduszu } & Wig & sWig80 & InvestorMS \\
\hline Wszystkie & 0,008 & $0,08^{*}$ & $-0,06^{*}$ \\
\hline Akcyjny & $-0,03$ & 0,03 & $-0,04$ \\
\hline Dłużne & 0,02 & $0,07^{*}$ & 0,07 \\
\hline Mieszane & $-0,0$ & $0,05^{*}$ & $-0,09^{*}$ \\
\hline Nieruchomości & 0,02 & $0,05^{*}$ & $-0,0$ \\
\hline Pozostałe & 0,001 & 0,01 & $-0,03$ \\
\hline
\end{tabular}

* $p=0,05$.

Źródto: opracowanie własne.

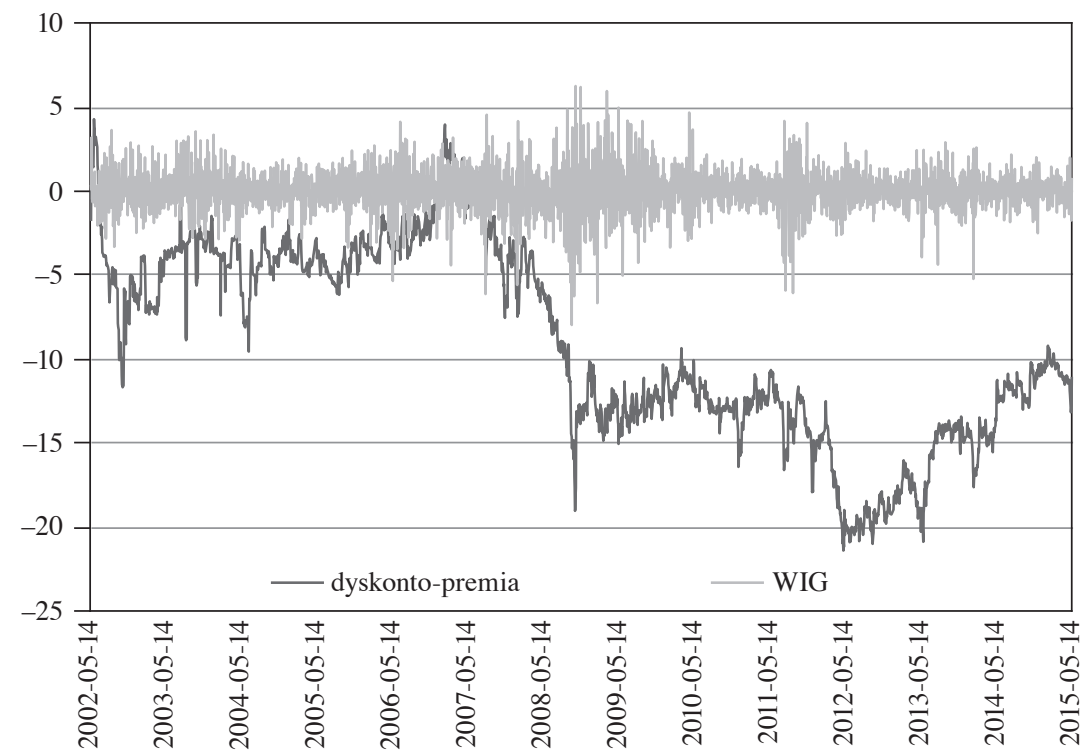

Rysunek 3. Przeciętna wartość dyskonta / premii na tle indeksu WIG w latach 2002-2015 (\%)

Źródło: opracowanie własne na podstawie danych z gpw.pl. 
nych przed terminem utrzymało się na porównywalnym poziomie. Zmiana nastąpiła tylko w liczbie transakcji, która zwiększyła się ponad dziesięciokrotnie.

W ostatnim etapie działalności funduszy inwestycyjnych, czyli przygotowaniu do likwidacji, dyskonto dla wszystkich funduszy uległo obniżeniu o 1 p.p., przy wzroście odchylenia standardowego o 3 p.p., obniżeniu wartości skrajnych oraz nieznacznym zwiększeniu liczby transakcji i prawie pięciokrotnym zmniejszeniu wolumenu obrotu. Poziom dyskonta dla funduszy zlikwidowanych przed terminem był w tym etapie najwyższy (7,3\%). Przygotowywanie funduszy do zakończenia działalności przełożyło się na zmniejszenie wolumenu obrotu przy stosunkowo wysokiej liczbie transakcji. Z kolei wysokość dyskonta dla funduszy utworzonych na czas określony w porównaniu z poprzednim etapem zmniejszyła się o 2 p.p. przy porównywalnym odchyleniu standardowym. Natomiast liczba transakcji przy zbliżonym wolumenie obrotu zwiększyła się ponad sześciokrotnie (z 0,8 $\mathrm{mln}$ do prawie $5 \mathrm{mln}$ ).

\subsection{Zależność wysokości dyskonta/ premii od indeksów giełdowych}

Jak wspomniano wcześniej, poziom dyskonta/ premii funduszy inwestycyjnych charakteryzuje się wysoką korelacją między różnymi rodzajami funduszy oraz klasami aktywów, w które najczęściej inwestują drobni inwestorzy. W przypadku badanych certyfikatów inwestycyjnych funduszy również występują statystycznie istotne zależności. W tabeli 5 przedstawiono macierz wartości współczynników korelacji rangowej Spearmana, która waha się od słabej do średniej.

$\mathrm{Na}$ podstawie wyników badania współczynnika korelacji rangowej Spearmana cen certyfikatów inwestycyjnych i indeksu WIG należy stwierdzić, że zależność między tymi zmiennymi nie występuje (rysunek 3). Wartości współczynników korelacji dla wszystkich i poszczególnych rodzajów funduszy oscylują wokół zera i nie są statystycznie istotne. $Z$ kolei zależność $\mathrm{z}$ indeksem sWIG80 okazała się różna od zera zarówno dla wszystkich funduszy, jak i dla poszczególnych rodzajów (z wyjątkiem funduszy akcyjnych i pozostałych). Natomiast zależność $z$ indeksem InvestorMS jest statystycznie istotna tylko w przypadku wszystkich funduszy oraz mieszanych. Dla pozostałych rodzajów funduszy zależność nie ma oczekiwanych właściwości. Wartości współczynników korelacji rang dla poszczególnych rodzajów funduszy oraz indeksów przedstawiono $\mathrm{w}$ tabeli 6 .

\section{Wnioski}

\subsection{Analiza zjawiska paradoksu funduszy zamkniętych}

Pierwszym celem artykułu było zbadanie istniejącego na polskim rynku funduszy inwestycyjnych zjawiska paradoksu funduszy zamkniętych. Na podstawie uzyskanych wyników można stwierdzić, że występująca również w Polsce rozbieżność między ceną giełdową a wartością księgową wykazuje wszystkie cechy charakterystyczne, które zostały zaobserwowane na rynkach rozwiniętych:

- połowa nowo wprowadzonych na giełdę certyfikatów była notowana powyżej WANCI i po upływie 31 sesji ich wartość spadła poniżej wyceny księgowej. Dla wszystkich funduszy okres ten wynosi tylko osiem sesji, co można wyjaśnić małą płynnością rynku oraz udziałem w próbie badawczej funduszy, które osiągały niskie stopy zwrotu ze względu na budowanie portfela inwestycyjnego (m.in. fundusze nieruchomości); 
- certyfikaty inwestycyjne były notowane wlatach 2002-2015 przeciętnie z dyskontem w wysokości 11\% (dyskonto występuje niezależnie od rodzaju funduszu);

- zarówno w krótkich, jak i w długich okresach poziom dyskonta / premii ulegał znacznym wahaniom.

Ostatnia cecha paradoksu, czyli obniżenie poziomu dyskonta w końcowym etapie działalności funduszy, nie została w pełni spełniona, co jest zgodne $\mathrm{z}$ oczekiwaniami. Cecha ta została zbadana dla rynków, na których istnieje możliwość przekształcenia funduszu z zamkniętego w otwarty. To z kolei powoduje, że inwestorzy oczekują zrównania lub zbliżenia ceny tytułu uczestnictwa do wartości księgowej. W Polsce nie ma takiej możliwości, a likwidacja funduszu wiąże się z dodatkowymi kosztami, które powodują zmniejszenie WANCI. Możliwość „przygotowania się” inwestorów do likwidacji funduszu wpływa na zmniejszanie poziomu dyskonta, co zostało zaobserwowane dla funduszy likwidowanych w terminie. Natomiast certyfikaty funduszy, które zakończyły działalność przed planowanym terminem, notowane były Z wyższym dyskontem niż wcześniej przy niższym odchyleniu standardowym i najniższym zróżnicowaniu ze wszystkich etapów.

C.M.C. Lee i in. (1991) udokumentowali, że w okresach wzrostu premii lub zmniejszania dyskonta następuje zwiększenie liczby funduszy inwestycyjnych, które dopuszczają tytuły uczestnictwa do obrotu wtórnego. $\mathrm{Na}$ podstawie uzyskanych wyników badania można potwierdzić, że podobne zjawisko występuje na polskim rynku. Spadek poziomu dyskonta wiąże się ze zwiększeniem liczby nowych certyfikatów na giełdzie (np. w 2006 r. wprowadzono osiem certyfikatów, rok później kolejnych pięć oraz w 2014 r. trzy). I odwrotnie, wzrost dyskonta zwiększa ostrożność zarządzających, jeżeli chodzi o dopuszczanie certyfikatów do publicznego obrotu, co widoczne jest w szczególności w latach 2009-2013 (tylko jeden nowy certyfikat rocznie).

W okresie budowania portfela certyfikaty notowane były z premią tylko do ósmej sesji. Od następnej certyfikaty wyceniano poniżej wartości księgowej. W kolejnym etapie, zarządzania lokatami, poziom dyskonta zwiększył się dwukrotnie. Z kolei w ostatnim etapie nieznacznie się obniżył (spadek o 0,8 p.p.). Występowanie dyskonta można wyjaśnić zmianą struktury inwestorów oraz opieraniem się przez nich na danych historycznych. Już na pierwszym etapie nastąpił wzrost udziału drobnych inwestorów przy wycofywaniu się racjonalnych inwestorów, o czym świadczy rozdrobnienie transakcji. Im dalej od pierwszego notowania, tym więcej transakcji przeprowadzanych było na kilka lub kilkanaście certyfikatów. Dodatkowo fundusze osiągały niskie stopy zwrotu ze względu na budowanie portfeli inwestycyjnych, a jak wykazano wcześniej, im niższe stopy zwrotu, tym niższy poziom premii i wyższe dyskonto. Podobne tendencje zostały zaobserwowane $\mathrm{w}$ okresie zarządzania lokatami, co w połączeniu z dłuższym czasem trwania tego etapu przełożyło się na zwiększenie poziomu dyskonta. Natomiast $\mathrm{w}$ ostatnim etapie, przygotowania do likwidacji, poziom dyskonta uległ podwyższeniu w przypadku funduszy zlikwidowanych przed planowanym czasem i zmniejszeniu dla funduszy utworzonych na czas określony. Opierając się na wynikach badania, można udzielić twierdzącej odpowiedzi na postawione we wstępie pytanie. Poziom dyskonta/premii wszystkich funduszy jest różny w poszczególnych etapach funkcjonowania funduszy (testy istotności dla średnich są statystycznie istotne przy $p=0,05$ dla poszczególnych grup i wszystkich funduszy, $\mathrm{z}$ wyjątkiem średnich dla wszystkich funduszy 
z etapu zarządzania lokatami i przygotowania do likwidacji).

\subsection{Analiza zachowań inwestorów i ich wpływ na poziom dyskonta / premii}

C.M.C. Lee i in. (1991) oraz N. Chopra $i$ in. (1993) wykazali na przykładzie USA, że na poziom dyskonta na rynku funduszy oraz wysokość stóp zwrotu $\mathrm{z}$ akcji małych i średnich spółek mają wpływ decyzje inwestorów nieracjonalnych. Uzyskane wyniki korelacji rangowej średnich stóp zwrotu funduszy inwestycyjnych z poziomem dyskonta/premii oraz $\mathrm{z}$ indeksami giełdowymi pozwalają wyciągnać podobne wnioski w odniesieniu do polskiego rynku. A. Szyszka (2003) zwraca uwagę, że wraz ze wzrostem udziału drobnych inwestorów czynniki nieracjonalne mają coraz większy wpływ na kształtowanie się notowań. Potwierdza to:

- wartość współczynnika korelacji rangowej średnich stóp zwrotu funduszy z wysokością dyskonta/premii na poziomie 0,4. Wzrost historycznych stóp zwrotu zwiększa optymizm drobnych inwestorów i obniża poziom dyskonta i zwiększa premie. $Z$ kolei słabsze wyniki inwestycyjne pogłębiają pesymizm inwestorów i tym samym poziom dyskonta oraz zmniejszają wysokość premii;

- brak korelacji między poziomem dyskonta/ premii i indeksem WIG, przy czym widoczne jest powiązanie tych zmiennych. W okresie hossy na rynku akcji (w szczególności w latach 2006 i 2007) certyfikaty notowane były z premią. Po załamaniu się koniunktury i wzroście niepewności na rynku certyfikaty wyceniane były znacznie poniżej wartości księgowej (Szyszka, 2009, s. 141). Zbliżone wnioski można wyciągnać na podstawie danych $\mathrm{z}$ kolejnych lat oraz relacji sWIG80 i poziomu dyskonta/premii funduszy. Wzrost niepewności w segmencie małych spółek powoduje zwiększanie poziomu dyskonta;

- średnia siła korelacji wzajemnej pomiędzy poziomem dyskonta/premii poszczególnych rodzajów funduszy oraz słaba korelacja z notowaniami małych spółek;

- ujemna i słaba zależność poziomu dyskonta/premii badanych funduszy $z$ indeksem InvestorMS, który reprezentuje racjonalnych inwestorów.

Porównując przeciętne roczne wartości liczby transakcji i wolumen obrotu z poziomem dyskonta/premii i stóp zwrotu, można zauważyć zwiększoną aktywność inwestorów w trzech okresach (lata 2004, 2007 i 2014). W 2004 r. niska liczba transakcji i wysoki wolumen obrotu wynikał z wprowadzenia do obrotu sześciu nowych certyfikatów inwestycyjnych. Natomiast spośród czynników, które wpłynęły na wzrost liczby transakcji i wolumenu obrotu w 2007 r., wskazać można wprowadzenie do obrotu pięciu nowych certyfikatów (rok wcześniej wprowadzono certyfikaty aż ośmiu funduszy) oraz obserwowany od 2004 r. coroczny wzrost średnich stóp zwrotu (maksimum w 2007 r.). Przy tym największy wpływ miał poziom dyskonta/premii funduszy akcyjnych oraz nieruchomości, który osiągnął dla tych funduszy rekordowe wartości. Certyfikaty funduszy akcyjnych notowane były $\mathrm{z}$ premią $1,1 \%$, a funduszy nieruchomości - ponad 10\%. Z kolei w 2014 r. inwestorzy zareagowali głównie na zmniejszenie poziomu dyskonta i wzrost stóp zwrotu funduszy surowcowych i absolutnej stopy zwrotu.

\section{Podsumowanie}

Przeprowadzone badanie wskazuje na wpływ decyzji inwestorów nieracjonalnych na poziom 
rozbieżności między ceną certyfikatów inwestycyjnych a wartością księgową. Wpływ ten ma różną siłę oraz zależy głównie od rodzaju funduszu inwestycyjnego i etapu, w jakim się on znajduje. Dobrym przykładem oddziaływania czynników nieracjonalnych na cenę certyfikatów są notowania tytułów uczestnictwa w funduszu Skarbiec Rynku Nieruchomości, którego strategia inwestycyjna zakładała lokowanie środków tylko w spółki z sektora nieruchomości notowanych na GPW w Warszawie. Oznacza to, że ceny certyfikatów powinny być wyznaczane przez bieżące ceny akcji pomniejszone o koszty funkcjonowania funduszu. Tymczasem średni poziom dyskonta wynosi $20,7 \%$ oraz jest ujemnie skorelowany $z$ indeksem WIG-Deweloperzy $(-0,06$ przy $p=0,05)$ i nieskorelowany $z$ indeksem WIG-Budownictwo. Drugim przykładem może być Investor FIZ, dla którego M. Pauka i P. Prędkiewicz (2015) wykazali istotny poziom korelacji pomiędzy poziomem dyskonta/premii a zachowaniem inwestorów w okresach miesięcznych (częstotliwość podawania przez ten fundusz wartości księgowej aktywów).

W przyszłych badaniach warto skupić uwagę na wpływie informacji publikowanych przez fundusze na kształtowanie się poziomu dyskonta/premii oraz zidentyfikowanie zachowań inwestorów i ich psychologiczne podłoże.

\section{Literatura}

Anderson, S., Beard, T.R., Kim, H., Stern, L.V. (2013). Fear and Closed-end Fund Discounts. Applied Economics Letters, 20(10), 956-59.

Bodurtha, J.N., Dong-Soon, K., Lee, C.M.C. (1995). Closed-end Country Funds and U.S. Market Sentiment. Review of Financial Studies, 8(3), 879-918.

Brickley, J.A., Schallheim, J.S. (1985). Lifting the Lid on Closed-end Investment Companies: A Case of Abnormal
Returns. The Journal of Financial and Quantitative Analysis, 20(1), 107-17, doi: 10.2307/2330680.

Charrón, M. (2009). The Closed-end Fund Puzzle: A Survey Review. Forum Empresarial, 14(2), 39-57.

Cherkes, M. (2012). The 2012 Survey of Closed-end Funds' Literature. SSRN Journal. doi: 10.2139/ssrn.2062336.

Chopra, N., Lee, C.M.C., Shleifer, A., Thaler, R.H. (1993). Yes, Discount on Closed-end Funds Are a Sentiment Index. Journal of Finance, XLVII(2), 801-8, doi: 10.1111/ j.1540-6261.1993.tb04742.x.

Chu, Y., Ma, L. (2015). Costly Arbitrage and the Closed-end Fund Puzzle: Evidence from a Natural Experiment. SSRN Journal. doi: 10.2139/ssrn.2621898.

Cieślak, A. (2003). Behawioralna ekonomia finansowa. Modyfikacja paradygmatów funkcjonujacych w nowoczesnej teorii finansów. Materiały i Studia, nr 165, Warszawa: Narodowy Bank Polski.

De Long, J.B., Shleifer, A., Summers, L.H., Waldmann, R.J. (1990). Noise Trader Risk in Financial Markets. Journal of Political Economy, 98(4), 703-38. doi: 10.1086/261703.

Dimson, E., Minio-Kozerski, C. (1999). Closed-end Funds: A Survey. Financial Markets, Institutions and Instruments, 8(2), 1-41. doi: 10.1111/1468-0416.00027.

Dimson, E., Minio-Paluello, C. (2002). The Closed-end Fund Discount, Charlottesville: Association for Investment Management and Research.

Fletcher, M. (2013). Liquidity, Sentiment and Segmentation: A Survey of Closed-end Fund Literature. SSRN Journal. doi: 10.2139/ssrn.2309974.

Lee, C.M.C., Shleifer, A., Thaler, R.H. (1990). Anomalies: Closed-end Mutual Funds. Journal of Economic Perspectives, 4(4), 153-64. doi: 10.1257/jep.4.4.153.

Lee, C.M.C., Shleifer, A., Thaler, R.H. (1991). Investor Sentiment and the Closed-end Fund Puzzle. The Journal of Finance, 46(1), 75-109. doi: 10.1111/j.1540-6261.1991. tb03746.x.

Lenkey, S.L. (2015). The Closed-end Fund Puzzle: Management Fees and Private Information. Journal of Financial Intermediation, 24(1), 112-29. doi: 10.1016/j. jfi.2014.11.001. 
Pauka, M., Prędkiewicz, P. (2012). Zagadka dyskonta w wycenach zamkniętych funduszy inwestycyjnych z perspektywy inwestora. Prace Naukowe Uniwersytetu Ekonomicznego we Wrocławiu, 271, 127-40.

Pauka, M., Prędkiewicz, P. (2015). Determinanty dyskonta w notowaniach certyfikatów inwestycyjnych zamkniętych funduszy inwestycyjnych na przykładzie FIZ Investors. Zeszyty Naukowe Uniwersytetu Szczecińskiego. Finanse. Rynki Finansowe. Ubezpieczenia, 75, 355-67.

Peavy, J.W. (1990). Returns on Initial Public Offerings of Closed-end Funds. Review of Financial Studies, 3(4), 695-708. doi: 10.1093/rfs/3.4.695.

Schleifer, A., Summers, L.H. (1990). The Noise Trader Approach to Finance. Journal of Economic Perspectives, 4(2), 19-33. doi: 10.1257/jep.4.2.19.

Stępień, M. (2010). Paradoks funduszy inwestycyjnych zamkniętych. Studia i Prace Kolegium Zarządzania, Zeszyt Naukowy 97, 131-45.

Szyszka, A. (2003). Ograniczenia arbitrażu a efektywność rynku kapitałowego. Studia Ekonomiczne, 3, 211-26.
Szyszka, A. (2007). Wycena papierów wartościowych na rynku kapitałowym w świetle finansów behawioralnych. Poznań: Wydawnictwo Uniwersytetu Ekonomicznego w Poznaniu.

Szyszka A. (2009). Finanse behawioralne. Nowe podejście do inwestowania na rynku kapitałowym. Poznań: Wydawnictwo Uniwersytetu Ekonomicznego w Poznaniu.

Szyszka, A., Zaremba A. (2009). Źródła i skutki ograniczeń arbitrażu na rynku papierów wartościowych. W: D. Zarzecki (red.), Czas na pieniądz. Zarządzanie finansami, t. II: Wycena przedsiębiorstw i zarządzanie wartościq (s. 243-53). Szczecin: Wydawnictwo Uniwersytetu Szczecińskiego.

Thompson, R. (1978). The Information Content of Discounts and Premiums on Closed-end Fund Shares. Journal of Financial Economics, 6(2-3), 151-86. doi: 10.1016/0304-405x(78)90028-4.

Weiss, K. (1989). The Post-offering Price Performance of Closed-end Funds. Financial Management, 18(3), 57-67. doi: 10.2307/3665649. 